\title{
PENGARUH KEMITRAAN TERHADAP KEUNTUNGAN USAHA PENGGEMUKAN DOMBA DI KABUPATEN BOGOR
}

\author{
Muhamad Yunus ${ }^{1)}$, Harianto ${ }^{2)}$ dan Dwi Rachmina ${ }^{3)}$ \\ ${ }^{1,2,3)}$ Departemen Agribisnis, Fakultas Ekonomi dan Manajemen,Institut Pertanian Bogor \\ ${ }^{1)}$ muhamad.yunus.du2@gmail.com
}

\begin{abstract}
Bojong Jengkol Village Ciampea Bogor is the production center of male sheep. To overcome thecapital, management, and marketing problem in male sheep fattening, having a partnership with CV. Mitra Tani Farm is one of the solution for the farmer, though not all of the farmers in the village participate in the partnership.This study aims to analyse the implementation of the partnership, to describe the farming performance with descriptive analysis, and to comparethe male sheep fatteningprofitof farmers who have a partnership with Mitra Tani Farm to that ofthose who do not. The results show that the non-partnership farmer obtainesthe highest ratio of profit to cash cost per SDD per period. On the other hand, in all scale, the ratio of profit to total cost per SDD per period is negative, which can be concluded that the fattening business is disadvantaging. However, the ratio of profit to total costof the partnership farmers better than that of non-partnership farmer since they have the smallest loss.
\end{abstract}

Keyword(s): partnership, profit analysis, sheep feedlot.

\begin{abstract}
ABSTRAK
Desa Bojong Jengkol merupakan salah satu wilayah di Kecamatan Ciampea, Kabupaten Bogor dimana penduduknya banyak mengusahakan penggemukan domba jantan. Namun untuk mengembangkan usahanya, para peternak memiliki permasalahan seperti permodalan, manajemen, dan pemasaran. Salah satu solusi untuk mengatasi permasalahan tersebut yaitu melalui kemitraan dengan CV. Mitra Tani Farm. Namun tidak semua peternak domba melakukan kemitraan dengan CV. Mitra Tani Farm.Tujuan dari penelitian ini yaitu untuk menganalisis pelaksanaan kemitraan dan mendeskripsikan keragaan usaha ternak menggunakan analisis deskriptif. Selain itu untuk mengukur tingkat keuntungan usaha penggemukan domba jantan antara peternak mitra dengan peternak nonmitra. Hasil perhitungan keuntungan atas biaya tunai per SDD (Setara Domba Dewasa) per periode yang paling besar diperoleh peternak nonmitra. Sementara itu perhitungan keuntungan atas biaya total per SDD per periode menghasilkan nilai negatif untuk semua kelompok sehingga usaha ternak domba merugikan. Namun jika dibandingkan nilai keuntungan atas biaya total, maka usaha pada peternak mitra yang lebih baik dibandingkan skala lainnya karena kerugian yang diperoleh paling kecil.
\end{abstract}

Kata Kunci: analisis keuntungan, kemitraan, penggemukan domba.

PENDAHULUAN

Domba merupakan salah satu hewan ternak jenis ruminansia yang potensial dan terus dikembangkan di Indonesia.
Perkembangan ini dapat dilihat dari semakin meningkatnya populasi ternak domba setiap tahunnya. Tercatat bahwa laju pertumbuhan domba di Indonesia 
pada tahun 2010 sebesar 5,16\%, tahun 2011 sebesar 9,94 persen, dan tahun 2012 sebesar 13,82 persen atau sebanyak 13.420.000 ekor domba pada tahun 2012 . Terdapat tiga wilayah yang memiliki populasi domba terbesar di Indonesia, yaitu Jawa Barat, Jawa Tengah, dan Jawa Timur. Jawa Barat sebagai wilayah yang memiliki populasi domba terbesar di Indonesia yaitu mencapai 8.249.844 ekor pada tahun 2012 atau sebesar $61,47 \%$ dari total populasi domba nasional (Ditjennak 2012).

Pengembangan usahaternak domba telah banyak dilakukan terutama oleh peternak rakyat di pedesaan. Domba banyak diusahakan karena memiliki berbagai keunggulan, diantaranya yaitu mudah beradaptasi terhadap lingkungan dan memiliki daya tahan tubuh yang lebih kuat dibanding ternak jenis lain (Sudarmono dan Sugeng 2011). Selain itu juga tidak membutuhkan lahan yang luas dan mudahnya mendapatkan pakan hijauan dari lingkungan sekitar pedesaan. Pemasaran hasil usahaternak dombapun cukup menjanjikan, seperti yang dikemukakan oleh Pranadji dan Sudaryanto (1998), bahwa pasar untuk ternak domba masih terbuka luas baik pasar domestik maupun mancanegara. Pernyataan tersebut juga diperkuat oleh Wiradarya (2004), bahwa usahaternak domba memiliki peluang pemasaran yang sangat tinggi, yaitu mencapai sekitar 976.354 ekor/tahun (atau 18.775 ekor/minggu).

Namun demikian, usahaternak domba juga menghadapi berbagai permasalahan. Pertama, keterbatasan permodalan bagi peternak domba sehingga skala pengusahaan ternak relatif kecil
(Handewi et al. 1996). Kedua, secara umum peternak domba masih menggunakan teknologi yang sederhana serta pengelolaan atau manajemen ternak yang belum baik. Ketiga,penggunaan domba bibit yang kurang berkualitas atau belum memenuhi persyaratan sebagai domba pedaging (Maulana, 2013). Hal tersebut dikarenakan peternak domba tidak melakukan seleksi bibit yang baik (Winarso, 2010). Keempat, permasalahan dalam pemasaran yang belum pasti. Hal ini menurut Winarso (2010) karena peternak pada umumnya tidak mempunyai kemampuan melakukan hubungan dengan pasar ternak dan pasar konsumsi secara langsung dan mereka sangat tergantung dengan pedagang atau tengkulak. Berbagai permasalah tersebut menyebabkan tingkat keuntungan usahaternak domba masih rendah.

Upaya untuk mengatasi berbagai permasalahan tersebut salah satunya dapat ditempuh melalui kerja sama atau kemitraan. Hal ini sesuai dengan Keputusan Menteri Pertanian (2007) yang menyatakan bahwa kemitraan usaha merupakan salah satu upaya untuk tercapainya pembangunan pertanian modern yang berorientasi agribinis. Kemitraan menurut Susrusa et al. (2006) adalah suatu strategi bisnis yang dilakukan oleh dua pihak atau lebih dalam jangka waktu tertentu untuk meraih keuntungan bersama dengan prinsip saling membutuhkan, saling menguntungkan, dan saling memperkuat. Pola kemitraan yang pada umumnya dijalankan yaitu pola kemitraan Inti-Plasma yang merupakan hubungan antara petani, kelompok tani, atau kelompok mitra sebagai plasma 
dengan perusahaan inti yang bermitra usaha (Sumardjo et al. 2004).

Menurut Eaton dan Shepherd (2001), adanya kemitraan (contract farming) dapat memberikan berbagai manfaat bagi pihak-pihak yang terlibat khususnya bagi petani/peternak, yaitu mendapatkan layanan konsultasi dalam cara produksi, mendapatkan dana untuk permodalan, mendapatkan teknologi baru sehingga petani mendapatkan pengetahuan baru, serta dapat meminimalisasi risiko harga dan sebagai penunjang untuk pembukaan pasar baru. Selain itu, petani yang mengikuti kemitraan pada umumnya akan memiliki tingkat keuntungan yang lebih tinggi dibandingkan petani mandiri yang tidak mengikuti kemitraan (Bolwig et al.2009; Miyata et al.2009; Saigenji 2010). Namun, dapat juga memberikan hasil sebaliknya, yaitu petani nonmitra lebih tinggi tingkat keuntungannya dibandingkan petani mitra (Sari 2012; Yunus 2009). Hasil-hasil tersebut menunjukkan bahwa belum ditemukannya hasil empiris yang konsisten atau masih bersifat inconclusive mengenai pengaruh kemitraan.

Banyak upaya mengembangkan usaha peternakan melalui rekayasa organisasi produksi yang disebut kemitraan. Manfaat dari kemitraan bagi peternak mitra menurut Eaton dan Shepherd (2001) yaitu mendapatkan layanan seperti konsultasi teknik budidaya, mendapatkan permodalan, mendapatkan pengetahuan baru, serta adanya keterjaminan pasar danmampu meminimalisasi risiko harga. Karena itu kemitraan diharapkan mampu meningkatkan produksi dan keuntungan bagi peternak mitra.

Berdasarkan uraian tersebut, benarkah ada hubungan antara kemitraan dengan keuntungan yang akan didapatkan oleh peternak mitra. Karena itu perlu dilakukan analisis usaha penggemukan ternak domba dengan memperhitungkan penerimaan dan pengeluaran selama proses kegiatan usaha tersebut dijalankan. Berdasarkan uraian tersebut, maka tujuan penelitian ini adalah:

1. Menganalisis pelaksanaan kemitraan yang terjadi antara perusahaan dengan peternak mitra.

2. Mendeskripsikan keragaan usaha penggemukan ternak domba yang dilakukan oleh peternak mitra maupun peternak nonmitra.

3. Mengukur tingkat keuntungan dan nilai $\mathrm{R} / \mathrm{C}$ rasio yang diperoleh dalam usaha penggemukan domba antara peternak mitra dengan peternak nonmitra.

\section{METODE PENELITIAN \\ Lokasi dan Waktu Penelitian}

Penelitian dilakukan di Desa Bojong Jengkol, Kecamatan Ciampea, Kabupaten Bogor baik untuk peternak mitra maupun nonmitra. Penentuan lokasi penelitian dilakukan secara purposive atau sengaja atas dasar pertimbangan bahwa Kabupaten Bogor merupakan salah satu lokasi di Jawa Barat yang memiliki populasi domba yang cukup besar yaitu sebanyak 221.873 ekor pada tahun 2011 (Disnak Provinsi Jawa Barat 2012) dan khususnya Desa Bojong Jengkol merupakan lokasi dimana pelaksanaan kemitraan berlangsung. Sedangkan untuk lokasi 
perusahaan yaitu CV. Mitra Tani Farm (CV. MT Farm) berada di Desa Tegal Waru, Kecamatan Ciampea, Kabupaten Bogor. Waktu penelitian mulai dari persiapan yaitu dilakukan sejak November tahun 2012 dan pengambilan data dimulai pada Februari sampai Maret tahun 2013.

\section{Jenis dan Sumber Data}

Jenis data yang digunakan pada penelitian ini adalah data cross-sectional. Data yang digunakan bersumber dari data primer dan data sekunder baik kualitatif maupun kuantitatif. Data primer diperoleh melalui pengamatan langsung dilapangan dan wawancara langsung dengan responden. Sedangkan data sekunder diperoleh melalui pencarian dari berbagai studi pustaka dan literatur yang relevan dengan topik penelitian.

\section{Metode Pengumpulan Data dan Pengambilan Sampel}

Metode pengumpulan data yang digunakan yaitu metode survei, wawancara terstruktur dengan alat bantu kuesioner kepada peternak responden maupun kepada pihak CV. MT Farm, dan diskusi

Metode pengambilan sampel untuk peternak mitra menggunakan metode sensus, yaitu respondennya adalah semua peternak mitra dalam populasi. Sedangkan metode pengambilan sampel untuk peternak nonmitra menggunakan metode purposive sampling berdasarkan peternak domba yang melakukan usaha penggemukan ternak domba jantan dengan lama usaha penggemukan yang dipilih maksimal 8 bulan selama satu periode penggemukan. Jumlah peternak domba yang dijadikan responden pada penelitian ini berjumlah 32 peternak, yang terdiri dari peternak mitra sebanyak 12 peternak dan peternak nonmitra sebanyak 20 peternak.

\section{Metode dan Analisis Data}

\section{Analisis Deskriptif}

Analsis deskriptif bertujuan untuk menggambarkan pelaksanaan kemitraan yang terjalin antara CV. MT Farm dengan peternak domba di Desa Bojong Jengkol, Kecamatan Ciampea, Kabupaten Bogor. Selain itu juga untuk mendeskripsikan keragaan usaha penggemukan ternak domba jantan yang dilakukan oleh peternak mitra maupun peternak nonmitra.

\section{Analisis Keuntungan Usahatani}

Indikator keberhasilan suatu usaha penggemukan ternak domba jantan salah satunya dilihat dari besarnya keuntungan yang diperoleh peternak melalui analisis usahatani. Menurut Soekartawi et al. (1986), analisis usahatani memperlihatkan cara-cara petani memperoleh dana dengan memadukan sumberdaya yang ada seperti lahan, tenaga kerja, modal, waktu dan pengelolaan (manajemen) yang terbatas ketersediaanya. Karena itu perlu di-lakukan perhitungan untuk mengetahui penerimaan usahatani yang terbagi menjadi dua, yaitu penerimaan tunai dan penerimaan nontunai. Penerimaan usaha-tani dapat dirumuskan sebagai berikut (Soekartawi 1995) :

$$
\mathrm{TR}=\mathrm{Y} \times \mathrm{Py}
$$


dimana:

TR : total penerimaan

$\mathrm{Y}$ : produksi yang diperoleh dalam usaha ternak;

Py : harga Y.

Selanjutnya dilakukan perhitungan biaya usahatani yang dapat dibedakan menjadi dua, yaitu biaya tunai dan biaya tidak tunai (Tjakrawiralaksana 1985). Biaya tunai adalah semua biaya yang dibayarkan dengan uang, seperti biaya pembelian sarana produksi dan upah tenaga kerja luar keluarga.Sedangkan biaya tidak tunai atau nontunai digunakan untuk menghitung keuntungan peternak yang sebenarnya, jika penyusutan alat dan tenaga kerja dalam keluarga diperhitungkan.

Menurut Soekartawi et al. (1986), analsisis keuntungan usahatani bertujuan untuk mengetahui besar keuntungan yang diperoleh dari usahatani yang dilakukan oleh petani. Keuntungan usahatani dapat dihitung menggunakan rumus:

Keuntungan $(\pi)=\mathrm{TR}-\mathrm{TC}$

Keuntungan $(\pi)=(P \times Q)-($ Biaya Tunai

+ Biaya Diperhitungkan)

dimana:

$\pi \quad$ : keuntungan usahatani (Rp);

TR : total penerimaan $(\mathrm{Rp})$;

TC : total pengeluaran (Rp);

$P$ : harga (Rp);

Q : jumlah (satuan).

Analisis keuntungan dalam usaha penggemukan ternak domba jantan ini dibagi dua. Pertama, keuntungan atas biaya tunai, yaitu biaya yang benar-benar dikeluarkan oleh peternak (explicit cost). Kedua, keuntungan atas biaya total dimana semua input milik keluarga juga diperhitungkan sebagai biaya. Secara umum, tingkat keuntungan usaha penggemukan domba jantan sebagai berikut:

$$
\begin{gathered}
\pi \text { tunai }=\mathrm{TR}-\mathrm{BT} \\
\pi \text { total }=\mathrm{TR}-\mathrm{TC} \\
\mathrm{TC}=\mathrm{BT}-\mathrm{BD}
\end{gathered}
$$

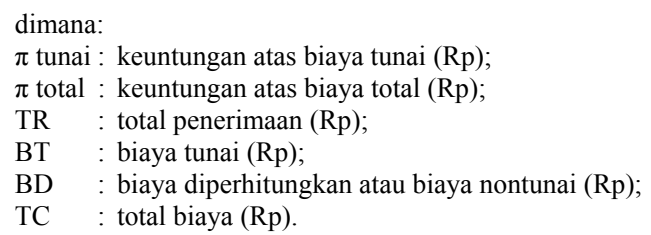

\section{Analisis $\mathbf{R} / \mathbf{C}$ Rasio}

Analisis imbangan penerimaan dan biaya $(\mathrm{R} / \mathrm{C})$ digunakan untuk mengetahui tingkat keuntungan relatif kegiatan usaha penggemukan ternak domba jantan. Rasio imbangan penerimaan dan biaya ini menunjukkan keuntungan kotor yang diterima untuk setiap rupiah yang dikeluarkan untuk beternak domba. Analisis $\mathrm{R} / \mathrm{C}$ rasio ini dibagi menjadi dua,yaitu $\mathrm{R} / \mathrm{C}$ rasio tunai dan $\mathrm{R} / \mathrm{C}$ rasio total. Secara matematis, keduanya dirumuskan sebagai berikut:

$$
\begin{aligned}
& \frac{\mathrm{R}}{\mathrm{C}} \text { rasio tunai }=\frac{\text { Total Penerimaan }(\mathrm{Rp})}{\text { Total Biaya Tunai }(\mathrm{Rp})} \\
& \frac{\mathrm{R}}{\mathrm{C}} \text { rasio total }=\frac{\text { Total Penerimaan }(\mathrm{Rp})}{\text { Total Biaya Total }(\mathrm{Rp})}
\end{aligned}
$$

Analisis rasio $\mathrm{R} / \mathrm{C}$ digunakan untuk menganalisis usahatani selama periode waktu tertentu. Apabila hasil perhitungan menunjukkan $\mathrm{R} / \mathrm{C}>1$, maka penerimaan yang diperoleh lebih besar dari tiap unit biaya yang dikeluarkan, maka dapat disimpulkan bahwa usahatani yang dijalankan menguntungkan. Apabila $\mathrm{R} / \mathrm{C}<1$, maka penerimaan yang diperoleh lebih kecil dari tiap unit biaya yang 
dikeluarkan, hal ini berarti usaha yang dijalankan tidak menguntungkan (Hernanto, 1995).

\section{HASIL DAN PEMBAHASAN Pelaksanaan Kemitraan}

Kemitraan yang dilaksanakan oleh CV. MT Farm dengan peternak domba di Desa Bojong Jengkol dimulai sejak Bulan Agustus tahun 2012. Latar belakang dibentuknya kemitraan ini yaitu sebagai program bina ekonomi masyarakat yang diprakarsai oleh CV. MT Farm dan BPZIS Bank Mandiri untuk membantu permodalan bagi peternak mitra yang melakukan usaha penggemukan ternak domba jantan. Selain itu, terdapat pihak lainnya yang dilibatkan dalam kemitraan ini, yaitu aparat desa yang memiliki peran dalam membantu penyaringan peternak domba yang akan dijadikan sebagai peternak mitra sebelum kemitraan dilaksanakan. CV. MT Farm memiliki beberapa peranan, diantaranya yaitu memberikan pendampingan dan pembinaan dalam teknis budidaya, menyediakan permodalan, menyediakan domba bibit/bakalan, menyediakan input atau faktor produksi (seperti obat-obatan, vitamin, dan peralatan), pengawasan dan kontrol secara rutin setiap hari, dan membeli kembali domba hasil penggemukan oleh peternak mitra. Secara lebih ringkas, proses pelaksanaan kemitraan tersebut dapat dijelaskan pada Gambar 1.

Pola kemitraan yang dijalankan yaitu pola inti-plasma, dimana adanya hubungan antara CV. MT Farm sebagai perusahaan inti dengan para peternak domba sebagai plasma. Persyaratan bagi peternak domba untuk menjadi mitra diantaranya yaitu memiliki/meyewa lahan untuk kandang, mampu mencari dan memenuhi pakan domba, serta memiliki tenaga kerja untuk pengelolaan dan pemeliharaan domba.

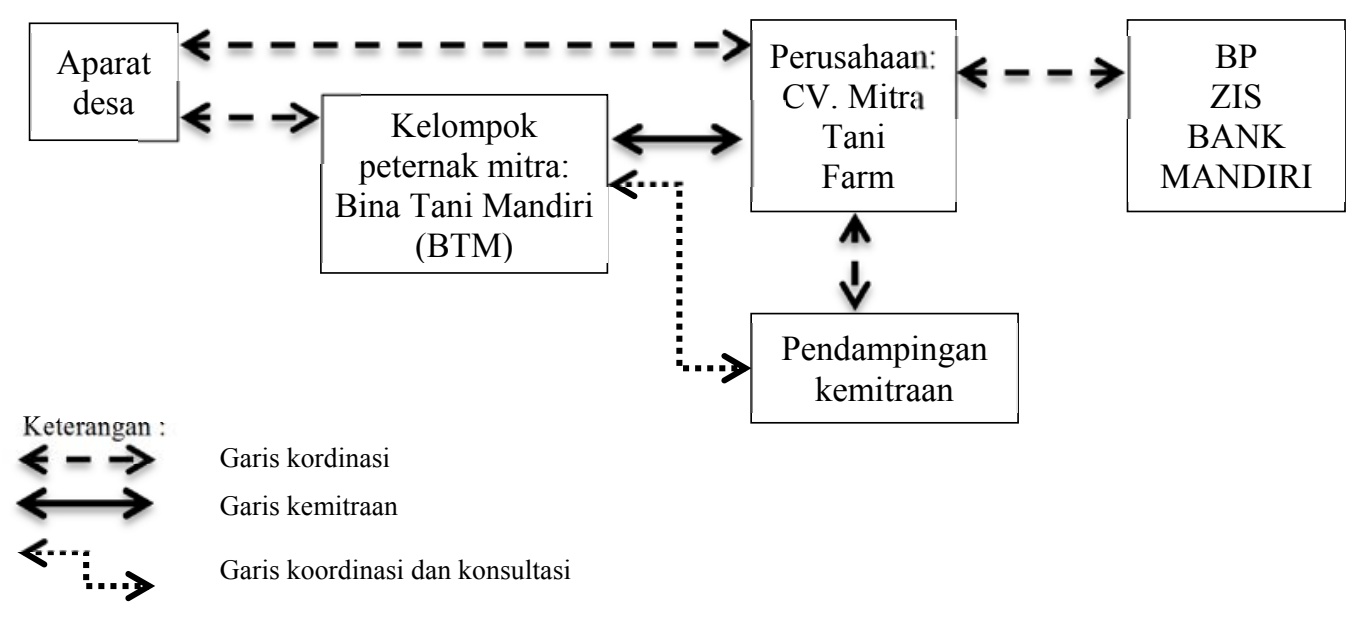

Gambar 1. Skema kemitraan CV. Mitra Tani Farm dengan peternak mitra 
Selain persyaratan yang harus dipenuhi oleh peternak mitra, terdapat juga kesepakatan yang telah dibuat yang merupakan hasil musyawarah dan disetujui oleh kedua belah pihak, diantaranya yaitu :

1. Pembagian hasil panen dihitung berdasarkan pertambahan bobot dari domba bibit per kilogramnya. Kesepakatan pembagian tersebut antara lain untuk peternak sebesar 50 persen, untuk investor/BPZIS Mandiri sebesar 25 persen, untuk Mitra Tani Farm sebesar 15 persen, dan untuk risiko sebesar 10 persen.

2. Pembagian biaya transportasi ditanggung oleh Mitra Tani Farm dan peternak mitra dengan proporsi 50:50. Besarnya biaya transportasi yang ditanggung oleh masing-masing pihak adalah Rp 250 per kilogram yang kemudian dikalikan dengan total bobot awal domba bibit yang diambil peternak dari kandang induk di MT Farm.

3. Apabila terjadi kematian pada ternak domba yang disebabkan oleh penyakit atau kehilangan ternak domba namun bukan disebabkan oleh kelalaian peternak, maka peternak mitra menanggung kerugian sebesar 25 persen dari harga beli domba bibit.

4. Sebagai bentuk motivasi bagi para peternak mitra, pihak perusahaan akan memberikan bonus berupa 1 ekor domba betina bibit jika rata-rata kenaikan bobot dari ternak domba yang digemukkan mencapai 2,25 kilogram per bulan untuk setiap ekor domba.
5. Adanya asuransi domba bibit yang diambil oleh peternak dari kandang induk selama satu hari.

Selanjutnya, mekanisme pelaksanaan kemitraan yang dilaksanakan diantaranya yaitu : (i) Proses pemilihan domba bibit; (ii) Proses pendampingan dan pengawasan kesehatan hewan; (iii) Kegiatan rapat dan evaluasi bulanan; (iv) Penimbangan bobot domba setiap bulan; dan (v) Penjualan ternak domba hasil penggemukan.

Pola pengusahaan ternak domba melalui kemitraan akan memberikan keuntungan-keuntungan bagi peternak mitra dibandingkan peternak nonmitra. Hal ini dapat dijelaskan pada Tabel 1.

\section{Keragaan Usahaternak}

Keragaan usahatani menunjukkan gambaran mengenai usaha yang dijalankan mulai dari awal kegiatan penyediaan sarana produksi hingga penanganan hasil/panen. Salah satu sarana yang harus dimiliki dalam usaha penggemukan ternak domba jantan adalah kandang. Kandang yang digunakan pada lokasi penelitian adalah kandang jenis panggung, yaitu bentuk bangunannya lebih tinggi dibandingkan lingkungan sekitarnya. Rata-rata ukuran kandang yang dibutuhkan untuk satu ekor domba jantan dewasa (umur $>12$ bulan) pada lokasi penelitian yaitu $1 \mathrm{~m}^{2}$. Ukuran ini sesuai dengan pedoman menurut BI (1998) untuk kebutuhan kandang domba jantan dewasa. Sedangkan untuk domba muda (umur 7-12 bulan) dan domba anak (umur 0-6 bulan) rata-rata membutuhkan ukuran $0,5 \mathrm{~m}^{2}$. 
Tabel 1. Keuntungan yang Diperoleh Peternak Mitra Melalui Kemitraan Dibandingkan Peternak Nonmitra

\begin{tabular}{|c|c|c|c|}
\hline No & Keuntungan & $\begin{array}{l}\text { Peternak } \\
\text { Mitra }\end{array}$ & $\begin{array}{l}\text { Peternak } \\
\text { Nonmitra }\end{array}$ \\
\hline 1. & Mendapatkan permodalan untuk pembelian domba bibit & $\sqrt{ }$ & $\left.\mathrm{X}^{*}\right)$ \\
\hline 2. & $\begin{array}{l}\text { Mendapatkan permodalan untuk pembuatan kandang } \\
\text { sebesar Rp2 } 000000 \text { per peternak }\end{array}$ & $\sqrt{ }$ & $\mathrm{X}$ \\
\hline 3. & $\begin{array}{l}\text { Mendapatkan pembinaan mengenai usaha ternak domba } \\
\text { baik secara teori maupun praktik, serta adanya } \\
\text { pendampingan dan pengawasan dalam melaksanakan } \\
\text { usaha ternak domba }\end{array}$ & $\sqrt{ }$ & $\mathrm{X}$ \\
\hline 4. & $\begin{array}{l}\text { Mendapatkan berbagai jenis obat-obatan untuk domba } \\
\text { serta pemeriksaan kesehatan domba }\end{array}$ & $\sqrt{ }$ & $\mathrm{X}$ \\
\hline 5 . & $\begin{array}{l}\text { Adanya keterjaminan pasar untuk hasil penggemukan } \\
\text { ternak domba oleh peternak }\end{array}$ & $\sqrt{ }$ & $\mathrm{X}$ \\
\hline & $\begin{array}{l}\text { Jan: }{ }^{*} \text { : Terdapat beberapa peternak nonmitra yang mendapatkan per } \\
\text { dengan sistem bagi hasil usaha. } \\
(\sqrt{ }): \text { Ya, } \\
(\mathrm{X}): \text { Tidak }\end{array}$ & untu & \\
\hline
\end{tabular}

Selain kandang, salah satu faktor penting dalam beternak domba adalah pakan. Jenis pakan yang digunakan oleh peternak responden yaitu hijauan seperti rumput-rumputan dan dedaunan (daun ubi, daun singkong, daun turi, dan daun jagung). Namun para peternak belum ada yang menggunakan pakan jenis lainnya seperti konsentrat, ampas tahu, maupun dedak karena terkendala dalam permodalan. Padahal untuk pakan konsentrat dapat meningkatkan kinerja ternak domba jantan yang dapat dilihat dari average daily gain (ADG) yang tinggi (Suhardi 2010).

Pada umumnya para peternak mencari pakan menggunakan peralatan seperti arit, alat pikul (cerangka, sundung, atau keranjang) dengan bobot pakan yang dapat diangkut rata-rata 50 kilogram per alat pikul. Rata-rata jumlah pakan yang diberikan untuk ternak domba yang berumur kurang dari 1 tahun yaitu sekitar 5 kilogram per ekor. Namun untuk ternak domba yang umurnya lebih dari 1 tahun membutuhkan pakan yang lebih banyak, yaitu sekitar 6 kilogram per ekor. Peralatan lainnya yang digunakan oleh peternak responden yaitu: asahan untuk mengasah arit; gunting bulu untuk mencukur bulu domba; cangkul cagak atau garpu tiga untuk membersihkan kotoran domba. Sedangkan untuk perlengkapan yang digunakan yaitu: karung sebagai wadah pakan hijauan dan sebagai wadah untuk kotoran; sapu lidi untuk membersihkan bagian dalam maupun luar kandang; sabun untuk memandikan domba; dan sikat untuk membersihkan bulu dan kulit domba.

Sistem pemeliharaan usaha penggemukan ternak domba jantan oleh responden baik peternak mitra maupun nonmitra semuanya dilakukan secara intensif, yaitu sistem pemeliharaan ternak domba di dalam kandang. Sistem pemeliharaan secara intensif ini akan menghasilkan produksi yang lebih tinggi dibandingkan secara ekstensif (Sugandi 2001). Faktor tenaga kerja juga me- 
rupakan hal penting yang perlu diperhatikan. Tenaga kerja yang digunakan oleh peternak responden adalah tenaga kerja dalam keluarga (TKDK) yang pada umumnya dilakukan oleh peternak dan dibantu oleh anaknya. Tenaga kerja yang digunakan dalam usaha ini tidak ada yang berasal dari luar keluarga karena skala usaha ternak domba yang mereka jalankan masih relatif kecil.

Kegiatan yang umum dilakukan dalam usaha penggemukan ternak domba jantan diantaranya yaitu mencari pakan, memberikan pakan secara rutin setiap harinya, membersihkan kandang, mencukur bulu domba, serta memandikan domba yang rutin dilakukan dalam jangka waktu tertentu.

Kesehatan domba juga perlu diperhatikan dalam usaha ini karena adanya kemungkinan domba terserang penyakit. Penyakit yang biasanya menyerang pada ternak domba responden diantaranya yaitu perut kembung, cacing, kudis atau kurap, dan sakit mata. Penanganan penyakit yang dilakukan oleh peternak nonmitra pada umumnya dengan membeli obat di toko obat atau dengan cara tradisional. Obat yang diberikan yaitu obat cacing dan vitamin serta ramuan tradisional. Sedangkan obat- obatan dan vitamin yang digunakan oleh peternak mitra yaitu telah disediakan dan ditanggung oleh pihak CV. MT Farm yang diberikan rutin oleh penanggung jawab (PJ) diantaranya yaitu,obat cacing atau albenol, antibiotik limoxin, ivermek untuk mengobati penyakit kurap pada domba, limoxyn sprey untuk mengobati penyakit mata, dan vitamin B kompleks.

Pemasaran ternak domba jantan dilakukan dengan penjualan domba hidup. Pemasaran ternak yang dilakukan oleh peternak mitra seluruhnya dijual kepada CV. MT Farm karena sudah ada perjanjian atau kontrak. Sedangkan untuk peternak nonmitra dalam memasarkan domba umumnya kepada para tengkulak maupun konsumen dengan sistem pemasaran yang secara langsung maupun berlangganan.

\section{Karakteristik Usahaternak}

Rata-rata kepemilikan domba jantan selama satu periode penggemukan yang dimiliki oleh peternak mitra maupun nonmitra secara lebih lengkap dapat dilihat pada Tabel 2. Semua ternak domba dalam penelitian ini disetarakan ke dalam setara domba dewasa (SDD), dimana satu SDD setara dengan satu ekor domba dewasa atau dua ekor domba muda atau empat ekor domba anak.

Tabel 2. Jumlah Rata-Rata Kepemilikan Ternak Domba Selama Satu Periode

\begin{tabular}{lcccccc}
\hline \multirow{2}{*}{ Usia domba } & \multicolumn{3}{c}{ Peternak mitra (n=12) } & \multicolumn{3}{c}{ Peternak nonmitra (n= 20) } \\
\cline { 2 - 5 } & Jumlah (ekor) Rataan (ekor) & SDD & Jumlah (ekor) Rataan (ekor) & SDD \\
\hline $\begin{array}{l}\text { Jantan dewasa } \\
(>12 \text { bulan) }\end{array}$ & - & - & - & 22 & 1,10 & 22 \\
$\begin{array}{l}\text { Jantan muda } \\
(7-12 \text { bulan) }\end{array}$ & 210 & 17,50 & 105 & 142 & 7,10 & 71 \\
Jantan anak & - & - & - & - & - & - \\
$(0-6$ bulan) & - & 17,50 & 105 & 164 & 8,20 & 93 \\
\hline Jumlah & 210 & & & & & \\
\hline
\end{tabular}


Sedangkan rata-rata lamanya usaha penggemukan ternak domba jantan peternak responden berbeda antara satu peternak dengan peternak lain yang dibedakan menjadi tiga kelompok seperti yang ditunjukkan pada Tabel 3.

Lamanya usaha penggemukan yang dilakukan oleh peternak mitra yaitu sama, dimana semuanya kurang dari tiga bulan. Waktu penggemukan ini terbilang singkat karena pihak perusahaan harus menyuplai dari banyaknya permintaan pasar yang setiap hari membutuhkan daging domba. Selain itu juga untuk membantu para peternak mitra dalam hal keuangan dengan waktu panen yang cepat. Namun, lamanya penggemukan yang dilakukan oleh peternak nonmitra sangat beragam, mulai dari tiga bulan hingga delapan bulan lamanya.

\section{Penerimaan Usahaternak}

Penerimaan yang diperoleh pada usaha penggemukan ternak domba jantan berasal dari penjualan domba hidup dan penjualan kotoran. Perhitungan penerimaan, pengeluaran, dan keuntungan di bagi dua, yaitu per periode dan per bulan. Hal ini dimaksudkan untuk melihat perbandingan yang lebih setara, karena waktu atau lamanya satu periode penggemukan domba jantan yang dilakukan antar peternak berbeda satu dengan yang lainnya. Penerimaan berdasarkan penjualan per ekor domba pada peternak mitra (Kel. I) rata-rata yaitu sebesar Rp 850.609, peternak nonmitra (Kel. II) rata-rata yaitu sebesar $\mathrm{Rp}$ 823.236 dan peternak nonmitra (Kel. III) rata-rata yaitu sebesar $\mathrm{Rp}$ 1.043.493. Peternak nonmitra pada Kel. III menghasilkan penjualan terbesar untuk setiap ekornya karena pada kelompok ini waktu penggemukan lebih lama dibandingkan kelompok lainnya, sehingga domba yang dihasilkan memiliki bobot yang lebih besar.

Selanjutnya yaitu penerimaan dari penjualan kotoran domba dimana untuk harga per karungnya berbeda-beda. Ratarata penjualan kotoran domba selama satu periode penggemukan untuk harga per karung yang diterima peternak mitra (Kel. I) yaitu sebesar $\mathrm{Rp} 1.667$, peternak nonmitra (Kel. II) sebesar Rp 1.462, dan peternak nonmitra (Kel. III) sebesar Rp 2.643 .

Tabel 3. Pengelompokan Berdasarkan Lamanya Penggemukan Domba Jantan

\begin{tabular}{ccccccc}
\hline \multirow{2}{*}{$\begin{array}{c}\text { Lama } \\
\text { penggemukan } \\
\text { (bulan) }\end{array}$} & $\begin{array}{c}\text { Jumlah } \\
\text { peternak } \\
\text { (orang) }\end{array}$ & $\begin{array}{c}\text { Jumlah } \\
\text { domba } \\
\text { (ekor) }\end{array}$ & $\begin{array}{c}\text { Jumlah } \\
\text { SDD }\end{array}$ & $\begin{array}{c}\text { Jumlah } \\
\text { peternak } \\
\text { (orang) }\end{array}$ & $\begin{array}{c}\text { Jumlah } \\
\text { domba } \\
\text { (ekor) }\end{array}$ & $\begin{array}{c}\text { Jumlah } \\
\text { SDD }\end{array}$ \\
\hline$<3$ bulan (Kel I) & 12 & 210 & 105 & - & - & - \\
$3-5$ bulan (Kel II) & - & - & - & 13 & 95 & 51 \\
6 - 8 bulan (Kel III) & - & - & - & 7 & 69 & 42 \\
\hline Total & 12 & 210 & 105 & 20 & 164 & 93 \\
\hline
\end{tabular}


Penjualan ternak domba semua-nya masuk ke dalam penerimaan tunai. Sedangkan penjualan kotoran domba sebagian masuk ke dalam penerimaan tunai jika kotoran domba dijual kepada pihak lain, dan sebagian masuk ke dalam penerimaan nontunai jika kotoran domba digunakan secara pribadi oleh peternak sebagai pupuk untuk usaha pertanian mereka

Secara lebih lengkap ringkas dan jelas mengenai rata-rata penerimaan pada masing-masing kelompok dapat dilihat pada Tabel 4.

Hasil perhitungan menunjukkan bahwa penerimaan total yang diperoleh peternak responden per SDD per periode yang paling besar yaitu pada peternak mitra(Kel. I). Namun untuk peternak nonmitra (Kel. II \& III) pun nilainya tidak terlalu berbeda. Begitu pula jika perhitungan berdasarkan penerimaan per SDD per bulan, dimana peternak mitra (Kel. I) memiliki nilai yang paling besar dibandingkan peternak nonmitra (Kel. II \& III).

\section{Biaya Usahaternak}

Biaya yang dikeluarkan oleh peternak responden pada kegiatan usaha penggemukan ternak domba jantan terdiri atas dua komponen, yaitu biaya tunai (pembelian domba bibit/bakalan, obat-oatan, perlengkapan, listrik, sewa lahan, dan biaya angkut) dan biaya nontunai atau biaya yang diperhitungkan (penyusutan kandang, penyusutan peralatan, obatobatan, TKDK, sewa lahan, dan biaya angkut).

Besarnya biaya pembelian domba bibit berbeda-beda, tergantung umurnya (sekitar 2-4 bulan) dan kualitas dombanya. Peternak nonmitra (Kel. I) membeli domba bibit yang paling tinggi yaitu $\mathrm{Rp}$ 740.651 per ekornya. Sedangkan peternak nonmitra (Kel. II) sebesar Rp 533.156 dan (Kel. III) sebesar Rp 495.659. Pembelian domba bibit ini merupakan biaya yang paling tinggi yang dikeluarkan oleh peternak pada masing-masing kelompok per periodenya, yaitu Kel. I mencapai 98,84 persen dari biaya tunai secara keseluruhan, Kel. II mencapai 96,53 persen, dan Kel. III mencapai 95,49 persen. Sedangkan untuk biaya tunai lainnya nilainya kecil dan hampir sama biaya yang dikeluarkan masing-masing kelompok.

Sementara itu, untuk biaya nontunai yang paling tinggi yang dikeluarkan oleh masing-masing kelompok per periode adalah biaya TKDK. Biaya ini pada Kel. I mencapai 79,25 persen, Kel. II mencapai 85,52 persen, dan Kel. III mencapai 86,93 persen. Biaya TKDK memang tidak diperhitungkan oleh peternak, karena mereka tidak mengeluarkan secara langsung uangnya untuk membayar upah tenaga kerja. Padahal jika diperhitungkan biaya ini sangat besar dan dapat menyebabkan keuntungan yang diterima oleh peternak rendah. 
Tabel 4. Rata-Rata Penerimaan Usaha Penggemukan Ternak Domba

\begin{tabular}{lrr}
\hline \multicolumn{1}{c}{ Penerimaan } & Nilai (Rp/SDD/periode) & Nilai (Rp/SDD/bulan) \\
\hline Kel 1 (n=12) & & \\
Tunai & 1.667 .063 & 810.887 \\
Nontunai & 1.622 & 667 \\
Total & 1.668 .685 & 811.554 \\
\hline Kel 2 (n=13) & & \\
Tunai & 1.563 .173 & 401.541 \\
Nontunai & 5.538 & 1.385 \\
Total & 1.568 .711 & 402.926 \\
\hline Kel 3 (n=7) & & \\
Tunai & 1.618 .211 & 244.521 \\
Nontunai & 0 & 0 \\
Total & 1.618 .211 & 244.521 \\
\hline
\end{tabular}

Berdasarkan perhitungan tersebut dapat dikatakan bahwa biaya tunai yang dikeluarkan dalam usaha penggemukan ternak domba jantan sebagian besar untuk pembelian domba bibit. Sedangkan biaya nontunai yang dikeluarkan sebagian besar untuk biaya TKDK. Secara lebih lengkap rata-rata biaya yang dikeluarkan oleh masing-masing kelompok peternak dapat dilihat pada Tabel 5.
Biaya total terbesar yang dikeluarkan per SDD per periode, yaitu pada peternak nonmitra (Kel. III). Hal ini dikarenakan pada kelompok ini,waktu penggemukan ternak domba lebih lama dibandingkan kelompok lainnya. Sementara itu, jika perhitungan biaya tersebut per SDD per bulan, maka biaya total yang paling besar yaitu pada peternak mitra (Kel. I).

Tabel 5. Rata-Rata Biaya Usaha Penggemukan Ternak Domba

\begin{tabular}{lrc}
\hline \multicolumn{1}{c}{ Penerimaan } & Nilai (Rp/SDD/periode) & Nilai (Rp/SDD/bulan) \\
\hline Kel 1 (n=12) & & \\
Tunai & 1.467 .150 & 718.014 \\
Nontunai & 260.979 & 118.888 \\
Total & 1.728 .129 & 836.902 \\
\hline Kel 2 (n=13) & & \\
Tunai & 1.048 .049 & 269.517 \\
Nontunai & 922.771 & 238.569 \\
Total & 1.970 .820 & 508.086 \\
\hline Kel 3 (n=7) & & \\
Tunai & 876.403 & 133.021 \\
Nontunai & 1.540 .106 & 222.490 \\
Total & 2.416 .509 & 355.511 \\
\hline
\end{tabular}




\section{Keuntungan Usahaternak}

Selisih antara penerimaan dan biaya akan menghasilkan keuntungan usaha penggemukan domba jantan. Keuntungan usaha ini terbagi menjadi dua komponen, yaitu keuntungan atas biaya tunai dan keuntungan atas biaya total.

Hasil keuntungan yang diperoleh atas biaya tunai per SDD per periode menunjukkan bahwa keuntungan terbesar diperoleh pada usaha penggemukan ternak domba jantan peternak nonmitra (Kel. III). Hal ini dikarenakan waktu penggemukan selama satu periode pada kelompok lebih lama dibandingkan kelompok lainnya. Begitu pula dengan nilai $\mathrm{R} / \mathrm{C}$ rasio pada peternak nonmitra (Kel.III) memiliki nilai yang paling tinggi, yaitu sebesar 1,846 yang berarti bahwa untuk setiap satu rupiah yang dikeluarkan pada usaha ternak tersebut akan mendapatkan penerimaan sebesar 1,846 rupiah. Meskipun terdapat perbedaan nilai $\mathrm{R} / \mathrm{C}$ rasio dari ketiga kelompok tersebut, namun ketiganya memiliki nilai $\mathrm{R} / \mathrm{C}$ rasio lebih dari satu, yang artinya usaha penggemukan ternak domba jantan untuk semua kelompok menguntungkan jika diperhitungkan atas biaya tunai. Sedangkan perhitungan hasil keuntungan per SDD per bulan yang terbesar diperoleh pada Kel. II. Hasil ini menunjukkan bahwa untuk keuntungan atas biaya tunai baik per SDD per periode maupun per SDD per bulan peternak nonmitra (Kel. III maupun Kel. II) keuntungannya lebih tinggi dibandingkan peternak mitra (Kel. I).

Namun, secara keseluruhan usaha penggemukan ternak domba jantan yang dijalankan baik pada Kel. I, II, maupun III tidak menguntungkan karena memiliki nilai keuntungan yang negatif terhadap biaya total baik per SDD per periode maupun per SDD per bulan. Begitu pula dengan perhitungan $\mathrm{R} / \mathrm{C}$ rasio yang menghasilkan nilai kurang dari satu. Akan tetapi, jika dibandingkan, maka peternak mitra (Kel. I) lebih baik dibandingkan peternak nonmitra (Kel. II dan III). Hal ini dikarenakan keuntungan pada peternak mitra memiliki nilai negatif yang lebih kecil dan nilai $\mathrm{R} / \mathrm{C}$ rasio yang lebih besar dibandingkan peternak nonmitra.

Tabel 6. Rata-Rata Keuntungan Usaha Penggemukan Ternak Domba Jantan

\begin{tabular}{|c|c|c|c|c|c|c|}
\hline \multirow[b]{2}{*}{ Uraian } & \multicolumn{2}{|c|}{$\begin{array}{c}\text { Peternak mitra: } \\
\text { Kel. I }(n=12)\end{array}$} & \multicolumn{2}{|c|}{$\begin{array}{c}\text { Peternak nonmitra: } \\
\text { Kel. II }(n=13)\end{array}$} & \multicolumn{2}{|c|}{$\begin{array}{c}\text { Peternak nonmitra: } \\
\text { Kel. III }(n=7)\end{array}$} \\
\hline & $\begin{array}{c}\text { Nilai } \\
\text { (Rp/SDD/ } \\
\text { periode) }\end{array}$ & $\begin{array}{c}\text { Nilai } \\
\text { (Rp/SDD/ } \\
\text { bulan) }\end{array}$ & $\begin{array}{c}\text { Nilai } \\
\text { (Rp/SDD/ } \\
\text { periode) }\end{array}$ & $\begin{array}{c}\text { Nilai } \\
\text { (Rp/SDD/ } \\
\text { bulan) } \\
\end{array}$ & $\begin{array}{c}\text { Nilai } \\
\text { (Rp/SDD } \\
\text { /periode) } \\
\end{array}$ & $\begin{array}{c}\text { Nilai } \\
\text { (Rp/SDD/ } \\
\text { bulan) }\end{array}$ \\
\hline \multicolumn{7}{|c|}{ Keuntungan atas biaya tunai } \\
\hline Total Penerimaan & 1.668 .685 & 811.554 & 1.568 .711 & 402.926 & 1.618 .211 & 244.521 \\
\hline Total Pengeluaran & 1.467 .150 & 718.014 & 1.048 .049 & 269.517 & 876.403 & 133.021 \\
\hline Total Pendapatan & 201.535 & 93.540 & 520.662 & 133.409 & 741.808 & 111.500 \\
\hline $\mathrm{R} / \mathrm{C}$ rasio & 1,137 & 1,130 & 1,497 & 1,495 & 1,846 & 1,838 \\
\hline \multicolumn{7}{|c|}{ Keuntungan atas biaya total } \\
\hline Total Penerimaan & 1.668 .685 & 811.554 & 1.568 .711 & 402.926 & 1.618 .211 & 244.521 \\
\hline Total Pengeluaran & 1.728 .129 & 836.902 & 1.970 .820 & 508.086 & 2.416 .509 & 355.511 \\
\hline Total Pendapatan & $(59.444)$ & $(25.348)$ & (402.109) & $(105.160)$ & $(798.298)$ & $(110.990)$ \\
\hline $\mathrm{R} / \mathrm{C}$ rasio & 0,966 & 0,970 & 0,794 & 0,793 & 0,670 & 0,688 \\
\hline
\end{tabular}


Tabel 7. Keuntungan Peternak Mitra Setelah Bagi Hasil Kemitraan

\begin{tabular}{lcc}
\multicolumn{1}{c}{ Uraian } & $\begin{array}{c}\text { Nilai } \\
\text { (Rp/SDD/periode) }\end{array}$ & $\begin{array}{c}\text { Nilai } \\
\text { (Rp/SDD/bulan) }\end{array}$ \\
\hline $\begin{array}{l}\text { Penerimaan hasil penjualan domba } \\
\text { setelah bagi hasil (A) }\end{array}$ & 100.972 & 47.555 \\
Penerimaan hasil penjualan kotoran & & \\
domba (B) & 16.610 & 7.125 \\
\hline Total penerimaan peternak (C=A+B) & 117.582 & 54.680 \\
\hline Biaya total peternak (D) & 255.130 & 116.344 \\
Biaya tunai peternak (E) & 14.542 & 6.911 \\
\hline Keuntungan atas biaya total $(\mathrm{F}=\mathrm{C}-\mathrm{D})$ & $(137.548)$ & $(61.664)$ \\
Keuntungan atas biaya tunai $(\mathrm{G}=\mathrm{C}-\mathrm{E})$ & 103.040 & 47.769 \\
\hline
\end{tabular}

\section{Proporsi Biaya Usaha Penggemukan Domba Peternak Mitra}

Terdapat beberapa pihak yang terlibat dalam usaha penggemukan ternak domba jantan yang dilakukan oleh peternak mitra. Karena itu, untuk mengetahui besarnya proporsi dan kontribusi masingmasing pihak yang terlibat dalam kemitraan, maka dilakukan perbandingan antara faktor produksi yang dikeluarkan.

Besarnya proporsi biaya produksi per SDD per periode yang dikeluarkan oleh BPZIS Bank Mandiri merupakan yang paling besar, yaitu 84,44 persen yang terdiri dari biaya pembelian domba dan penyusutan kandang. Sedangkan biayayang ditanggung oleh CV. MT Farm yaitu sebesar 0,79 persen yang terdiri dari biaya obat-obatan dan biaya angkut, dimana untuk biaya angkut juga ditanggung oleh peternak dengan proporsi yang sama atau setengah dari biaya angkut. Sementara itu biaya produksi yang dikeluarkan oleh peternak mitra yaitu sebesar 14,77 persen yang terdiri dari biaya perlengkapan, biaya listrik, biaya angkut, biaya penyusutan peralatan, TKDK, dan biaya sewa lahan.
Selanjutnya, berdasarkan perhitungan, maka komposisi penerimaan, biaya, dan keuntungan peternak dapat dilihat pada Tabel 7.

\section{KESIMPULAN DAN SARAN}

\section{Kesimpulan}

1. Pelaksanaan kemitraan yang dijalankan sudah termasuk baik, karena sudah adanya persyaratan, perjanjian antar kedua belah pihak, serta adanya mekanisme pelaksanaan kemitraan yang jelas. Namun belum adanya perjanjian tertulis mengenai kemitraan tersebut karena hanya menerapkan azas "saling percaya".

2. Keragaan usaha penggemukan ternak domba jantan yang dilakukan oleh peternak mitra maupun peternak nonmitra hampir sama, khususnya dalam hal penggunaan inputseperti kandang, peralatan, perlengkapan dan tenaga kerja. Selain itu juga dalam teknik budidaya atau kegiatan pemeliharaan domba mulai dari mencari pakan, memberikan pakan, membersihkan kandang, memandikan domba, hingga mencukur bulu domba. Sedangkan perbedaanya yaitu dalam 
penggunaan obat-obatan dan pemasaran yang dilakukan.

3. Hasil analisis perhitungan tingkat keuntungan terbagi dua, yaitu keuntungan atas biaya tunai dan keuntungan atas biaya total. Keuntungan atas biaya tunai usaha yang dijalankan oleh peternak nonmitra lebih tinggi dibandingkan peternak mitra, namun sebaliknya keuntungan atas biaya total usaha yang dijalankan oleh peternak mitra lebih tinggi dibandingkan peternak nonmitra sehingga mengikuti program kemitraan memberikan pengaruh yang lebih baik dibandingkan tanpa mengikuti kemitraan. Waktu atau lamanya penggemukan juga akan mempengaruhi tingkat keuntungan yang diperoleh dalam usaha penggemukan ternak domba jantan.

\section{Saran}

Berdasarkan hasil dan pembahasan serta simpulan, maka terdapat beberapa saran dari penelitian ini, yaitu:

1. Peran penyuluh peternakan sangat diperlukan untuk membantu peternak domba dalam manajemen dan pemeliharaan domba yang baik. Selain itu juga untuk memberikan pengetahuan mengenai perhitungan terutama biaya-biaya nontunai yang pada umumnya tidak diperhitungkan dalam usaha ternak domba.

2. Keragaan usaha yang dilakukan oleh peternak domba pada lokasi penelitian masihrelatif sederhana, sebaiknya mengikuti standar yang ideal dalam hal penyediaan sarana produksi hingga penanganan pasca panen agar menghasilkan ternak domba yang berkualitas. Selain itu para peternak sebaiknya memaksimalkan kapasitas kandang yang tersedia untuk domba karena akan membuat keuntungan yang diperoleh lebih maksimal.

3. Perlu adanya kontrak kerjasama secara tertulis mengenai hak dan kewajiban antara perusahaan dan peternak. Hal tersebut bertujuan agar kedua belah pihak memiliki semangat dan komitmen yang tinggi dalam menjalankan kemitraan.

4. Perlu adanya peningkatan proses pendampingan dan pembinaan yang dilakukan oleh CV. MT Farm secara lebih intensif serta perlu adanya penambahan penanggung jawab peternak mitra yang memiliki pengetahuan yang baik mengenai ternak domba.

5. Bagi penelitian selanjutnya, perlu dilakukan evaluasi dan efektivitas kemitraan serta pengukuran tingkat kepuasan peternak mitra terhadap perusahaan kemitraan. Hal ini perlu dilakukan untuk mengetahui pelaksanaan kemitraan yaang telah dijalankan. Kemudian untuk analisis usahatani yang dilakukan sebaiknya diperhitungkan dalam kurun waktu satu tahun. Selain itu juga perlu dilakukan analisis efisiensi usahaternak domba untuk mengetahui tingkat penggunaan faktor produksi secara efisien karena akan berpengaruh terhadap produksi domba dan tingkat keuntungan. 


\section{UCAPAN TERIMA KASIH}

Ucapan terima kasih penulis sampaikan kepada Biro Perencanaan Kerjasama Luar Negeri, Kementerian Pendidikan dan Kebudayaan Republik Indonesia yang telah memberikan beasiswa pendidikan kepada penulis selama menempuh pendidikan master di Program Studi Magister Sains Agribisnis, Institut Pertanian Bogor.

\section{DAFTAR PUSTAKA}

[BI]. 1998. Pola Pembiayaan Usaha Kecil (PPUK) Pemeliharaan Domba. Bank Indonesia. Jakarta.

Bolwig, S., P. Gibbon, dan S. Jones. 2009. The Economics of Smallholder Organic Contract Farming in Tropical Africa. Elsevier Journal, World Development Vol. 37, No.6 pp. 1094-1104, 2009.

[Disnak]. 2012. Populasi Ternak Domba di Provinsi Jawa Barat Tahun 2011. Dinas Peternakan Provinsi Jawa Barat.

[Ditjennak]. 2012. Populasi Ternak Domba di Indonesia Tahun. Direktorat Jenderal Peternakan dan Kesehatan Hewan. Jakarta.

Eaton, Charles., Andrew W. Shepherd. 2001. Contract Farming Partnership for Growth. Food and Agriculture Organization of the United Nation, FAO Agricultural Services Buletin 145.
Handewi, P. S. Rachman, dan Sudaryanto. 1996. Karakteristik Usaha Ternak Domba di Daerah Lahan Kering (Kasus Dua Desa di Kabupaten Semarang dan Boyolali Jawa Tengah). Prosiding Temu Ilmiah Hasil-Hasil Penelitian Peternakan. Bogor (ID): Balai Penelitian Ternak, Puslitbang Peternakan, Badan Litbang Pertanian.

Hernanto, Fadholi. 1995. Ilmu Usahatani. Penebar Swadaya. Jakarta.

[Kementan]. 1997. Keputusan Menteri Pertanian Nomor: 940/Kpts/ OT.210/10/97 tentang Pedoman Kemitraan Usaha Pertanian. Kementerian Pertanian Republik Indonesia. Jakarta.

Maulana, Arief. 2013. Unpad dan 11 Instansi Bentuk Konsorsium Pengembangan Domba Padjajaran. Tersedia pada: http://www.unpad.ac.id/2013/06/u npad-dan-11-instansi-bentukkonsorsium-pengembangandomba-padjadjaran/

Miyata, S.,N. Minot, dan D. Hu. 2009. Impact of Contract Farming Ion Income: Linking Small Farmers, Packers, and Supermarkets in China. Elsevier Journal, World Development Vol. 37, No. 11, pp. 1781-1790, 2009.

Pranadji, T., B Sudaryanto. 1998. Kajian terhadap persepsi petani dan kelembagaan korporasi untuk pengembangan usahaternak domba di pedesaan: studikasus pada desadesa di Kecamatan Jambu, Kabupaten Semarang. Jurnal Ilmu Ternak dan Veteriner.Vol 4 No 2 Th 1999. 
Saigenji, Yoshiko. 2010. Contract Farming and Its Impact on Production Efficiency and Rural Household Income in the Vietnamese Tea Sector [Disertasi]. Faculty of Agricultural Sciences. University of Hohenheim. Stuttgart, Germany.

Sari, DP. 2012. Analisis Pendapatan Usahaternak Ayam Ras Pedaging Pola Kemitraan dan Mandiri di Kecamatan Gunung Sindur Kabupaten Bogor [Skripsi]. Departemen Ekonomi Sumberdaya dan Lingkungan, Fakultas Ekonomi dan Manajemen, Institut Pertanian Bogor. Bogor.

Soekartawi, A. Soeharjo, John L. Dillon, dan J. Brian Hardaker. 1986. Ilmu Usahatani dan Penelitian untuk Pengembangan Petani Kecil.UI Press. Jakarta.

Soekartawi. 1995. Ilmu Usahatani. Jakarta (ID): UI Press.

Sudarmono AS dan Sugeng YB. 2011. Beternak Domba. Penebar Swadaya. Jakarta.

Sugandi, D. 2001. Efisiensi Produksi Usahaternak Domba di Dataran Rendah Kabupaten Majalengka [Tesis]. Jurusan Ekonomi Pertanian, Universitas Gajah Mada. Yogyakarta.

Suhardi. 2010. Aplikasi Teknologi Pengolahan Pakan Konsentrat Ternak Ruminansia dengan Metode Pengukusan untuk Meningkatkan Tingkat Kecernaan Pakan dan Pertambahan Bobot Badan Harian. Jurnal Teknologi Pertanian. Vol. 6 No. 1.
Sumardjo, S. Jaka, dan A.D.Wahyu. 2004. Teori dan Praktik Kemitraan Agribisnis. Penebar Swadaya. Jakarta.

Susrusa, Budi K, Zulkifli, 2006. Efektifitas Kemitraan pada Usahatani Tembakau Virginia di Kabupaten Lombok Timur. Journal on Socio-Economics of Agriculture and Agribusiness (SOCA).

Tjakrawiralaksana A. 1985. Usahatani. Bogor (ID): Institut Pertanian Bogor.

Winarso, Bambang. 2010. Prospek dan Kendala Pengembangan Agribisnis Ternak Kambing dan Domba di Indonesia. Bogor (ID): Pusat Analisis Sosial Ekonomi dan Kebijakan Pertanian.

Wiradarya, TR. 2004. Tantangan dan Peluang Peningkatan Efisiensi Usaha Ternak Kambing dan Domba (Peternakan KambingDomba Skala Menengah Sistem 3 Strata: Pembibitan, Pembiakan dan Komersial) (Paper). Disajikan pada Lokakarya Nasional kambingdomba potong. Fakultas Peternakan, Institut Pertanian Bogor, Bogor.

Yunus, R. 2009. Analisis Efisiensi Produksi Usaha Peternakan Ayam Ras Pedaging Pola Kemitraan dan Mandiri di Kota Palu Provinsi Sulawesi Tengah [Tesis]. Universitas Diponegoro, Semarang. 
Muhamad Yunus, Harianto dan Dwi Rachmina 